\title{
Identification of Poison Ivy, Poison Oak and Poison Sumac in Florida ${ }^{1}$
}

Patricia Grace and Sherrie Lowe ${ }^{2}$

\section{Introduction}

Florida parks and woodlands are favorite places for many people who enjoy outdoor activities such as camping, hiking, fishing and biking. Unfortunately, every year numerous Floridians are accidentally poisoned by coming in contact with one of several plants typically found in these locations. The most common plant encountered is poison ivy. Poison oak and poison sumac are also found in some of these settings.

Contact with any of these plants can cause severe skin dermatitis. Poisoning results from contact with the sap of the plant. This can occur directly by touching the plant or indirectly by picking up the toxins from animals, clothes or other items. Particles in the smoke of the burning plant may carry toxins as well.

Symptoms may appear within a few hours or a few days. Itching and burning of the skin may be followed by a rash, redness, swelling and watery blistering. Infection of the blisters may cause systemic complications. Individuals vary in their susceptibility to these plants. Approximately $25 \%$ are not sensitive, but anyone may become sensitive after repeated exposure.

Poisoning by these plants is largely preventable. One can easily learn to identify these plants in their various forms with the aid of general descriptions and pictures and by observing plants in the wild. Children should also be taught to recognize these plants, particularly poison ivy, which is by far the most common. The purpose of this publication is to assist individuals in learning to identify these plants and avoid contact with them.

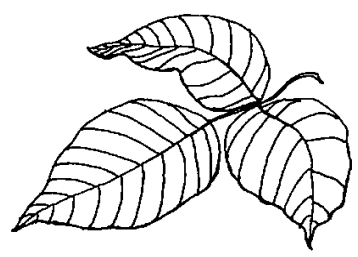

Figure 1. (Poison Ivy) Credits: Sherrie Lowe

\section{Poison Ivy, (Rhus radicans)}

Poison ivy is a woody shrub or vine with hairy looking aerial roots. It grows to 10 feet or more, climbing high on trees, walls and fences or trails along the ground. All parts of poison ivy, including

1. This document is Circular ENH886, one of a series of the Environmental Horticulture Department, Florida Cooperative Extension Service, Institute of Food and Agricultural Sciences, University of Florida. Original publication date April 29, 2003. Visit the EDIS Web Site at http://edis.ifas.ufl.edu.

2. Patricia Grace, Extension Horticulture Agent, Putnam County Cooperative Extension Service, Sherrie Lowe, Putnam County Master Gardener, University of Florida.

The Institute of Food and Agricultural Sciences (IFAS) is an Equal Employment Opportunity - Affirmative Action Employer authorized to provide research, educational information and other services only to individuals and institutions that function without regard to race, creed, color, religion, age, disability, sex, sexual orientation, marital status, national origin, political opinions or affiliations. For information on obtaining other extension publications, contact your county Cooperative Extension Service office. Florida Cooperative Extension Service / Institute of Food and Agricultural Sciences / University of Florida / Larry R. Arrington, Interim Dean 
the roots, are poisonous at all times of the year. They may flourish in the deep woods, where soil moisture is plentiful, or in very dry soil on the most exposed hillsides. Plants are most frequently abundant along old fence rows and edges of paths and roadways.

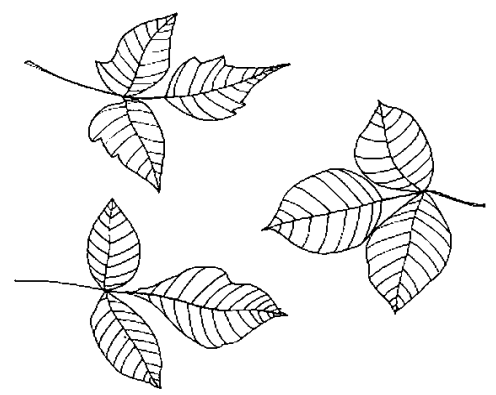

Figure 2. (Poison Ivy) Credits: Sherrie Lowe

Leaf forms among plants, or even on the same plant, are as variable as the habit of growth; however the leaves almost always consist of three leaflets. The old saying, "Leaflets three, let it be," is a reminder of this consistent leaf character. (See figures 1 and 2.)

Flowers and fruit are always in clusters on slender stems that originate in the axils, or angles, between the leaves and woody twigs. Berrylike fruits usually have a white, waxy appearance. (See figure 3.)

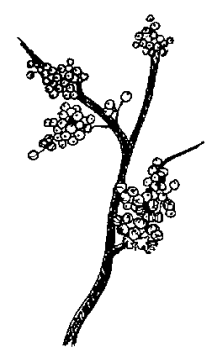

Figure 3. (Poison Ivy) Credits: Sherrie Lowe

\section{Poison Oak, (Rhus toxicodendron)}

Poison oak is more distinctive than some other types of ivy. Some people call it oakleaf ivy while others call it oakleaf poison ivy. Poison oak usually does not climb as a vine, but occurs as a low growing shrub. Stems generally grow upright. Leaflets occur in threes, as in other ivy, but are lobed, somewhat as the leaves of some kinds of oak.
The middle leaflet usually is lobed alike on both margins and resembles a small oak leaf, while the two lateral leaflets are often irregularly lobed. The range in size of leaves varies considerably, even on the same plant. (See figure 4.)

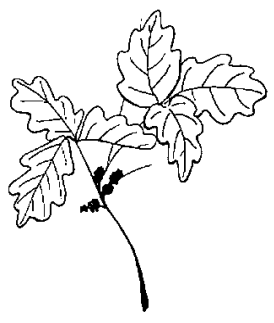

Figure 4. (Poison Oak) Credits: Sherrie Lowe

\section{Poison Sumac, (Rhus vernix)}

Poison sumac grows as a course woody shrub or small tree and never in the vinelike form of its poison ivy relatives. This plant is also known as swamp sumac, poison elder, poison ash, poison dogwood and thunderwood. It does not have variable forms, such as occur in poison ivy. This shrub is usually associated with swamps and bogs. It grows most commonly along the margin of an area of wet acid soil.

Mature plants range in height from 5 to 6 feet to small trees that may reach 25 feet. Poison sumac shrubs usually do not have a symmetrical treelike appearance. Usually, they lean and have branched stems with about the same diameter from ground level to middle height.

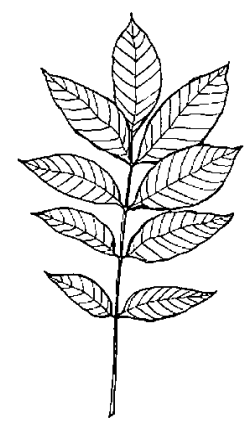

Figure 5. (Poison Sumac) Credits: Sherrie Lowe

Leaves of poison sumac consist of 7 to 13 leaflets arranged in pairs with a single leaflet at the end of the midrib. (See figure 5.) The leaflets are elongated oval without marginal teeth or serration. They are 3 to 4 inches long, 1 to 2 inches wide, and 
have a smooth, velvety texture. In early spring their color is bright orange. Later, they become dark green and glossy on the upper surface, and pale green on the lower, and have scarlet midribs ( a very distinctive feature). In the early fall, leaves turn to a brilliant red-orange or russet shade.

The small yellowish-green flowers are borne in clusters on slender stems arising from the axis of leaves along the smaller branches. Flowers mature into ivory-white or green-colored fruits resembling those of poison oak or poison ivy, but usually are less compact and hang in loose clusters that may be 10 to 12 inches in length. (See figure 6.)

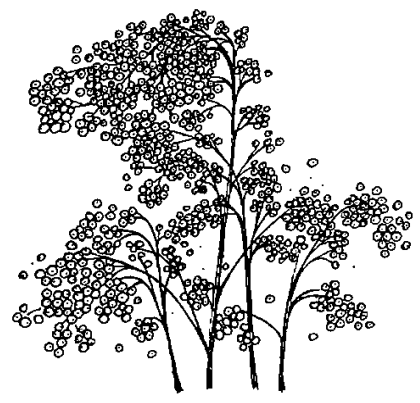

Figure 6. (Poison Sumac) Credits: Sherrie Lowe

Throughout most of the range where poison sumac grows, three nonpoisonous species may also occur. These are the smooth sumac (Rhus glabra), staghorn sumac (Rhus typhina) and dwarf sumac (Rhus copallina). All three species have red fruits that together form a distinctive terminal seed head.

These are easily distinguishable from the slender hanging clusters of the poison sumac.

The leaves of these three species also have some distinct characteristics. Leaves of the smooth sumac and of staghorn sumac have many leaflets, which are slender and lance shaped and have a toothed margin. These species usually have more than 13 leaflets.

Leaves of dwarf sumac and poison sumac have fewer leaflets and are more oval shaped with smooth or even margins. The dwarf sumac is readily distinguished from poison sumac by a winged midrib. Poison sumac never has the wing margin on the midrib.

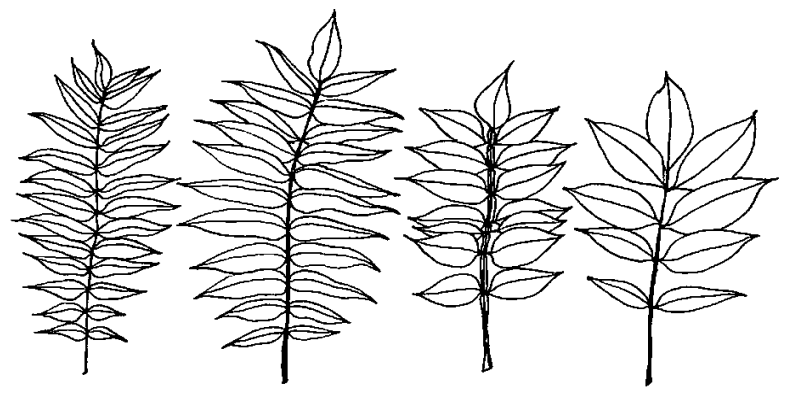

Figure 7. From left to right the pictured species are smooth sumac, staghorn sumac, dwarf sumac and poison sumac Credits: Sherrie Lowe

\section{Common Look-Alikes}

The most common poison ivy look-a-like is Virginia creeper (Parthenocissus quinquefolia). It can be distinguished from poison ivy rather easily. It has three to five divided leaflets. The leaflets are palmate like an outstretched hand. It has blue-black berries along the stem. It can be either trailing or climbing. (See figure 8.)

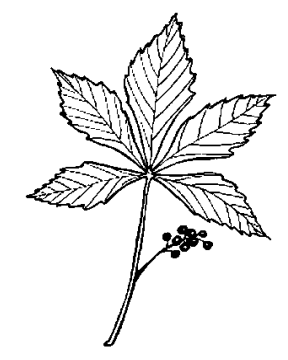

Figure 8. (Virginia Creeper) Credits: Sherrie Lowe 